\title{
EFFECTS OF THE REPUBLIC OF SERBIA'S CITIZENS' PATRIOTISM AND ANIMOSITY TOWARDS THE EUROPEAN UNION ON CONSUMER ETHNOCENTRISM
}

\author{
Veljko Marinkovic* \\ Faculty of Economics, University of Kragujevac, Kragujevac, The Republic of Serbia
}

Economic, political and militaristic tensions between countries are present throughout the world. The devastating effects of the global financial crisis are still generating the ever-increasing instability of the world economy. Patriotism and nationalism, as well as animosity towards the economic and military policies of certain foreign countries, seem to be on the rise across many countries and nations in recent years. It is precisely the current situation in the world that is favorable for encouraging citizens to purchase domestic products. The policy can be particularly useful for lessdeveloped import-oriented economies. Thus, in the conditions of the economic crisis, the study of consumer ethnocentrism is gaining in importance. The paper examines the effects of the patriotism of the citizens of the Republic of Serbia and animosity towards the EU on consumer ethnocentrism. The results show that both these variables stand out as the statistically significant antecedents of consumer ethnocentrism; however, it should be noticed that patriotism shows a stronger influence on the consumer's orientation towards buying domestic products. The research findings indicate that love of one's country may direct consumer choices towards domestic brands, despite the positive image and high quality of foreign ones. In addition, due to citizens' strong dislike towards the EU economic policy, some of them may decide to buy lower-quality domestic products; however, this does not necessarily negatively affect one's perception of foreign products.

Keywords: consumer ethnocentrism, patriotism, animosity, buying local products, confirmatory factor analysis, structural equation model

JEL Classification: M31, M37

\section{INTRODUCTION}

Whether it is desirable that the government should encourage citizens to purchase domestic products and whether such measures have a positive effect

* Correspondence to: V. Marinkovic, Faculty of Economics, University of Kragujevac, D. Pucara 3, 34000 Kragujevac, The Republic of Serbia; e-mail: vmarinkovic@kg.ac.rs on the growth of the national economy is quite an interesting question to be answered by the economic policy makers of a country. On the one hand, encouraging consumers to buy domestic products can indeed support the growth of domestic production and employment, especially when a particular country is facing an economic crisis, as well as in the case of less-developed and/ 
or import-oriented countries. On the other hand, whether it is justified to encourage consumers to buy lower-quality local products should be considered. Also, there is the issue of whether it is possible to implement this policy in the same manner in different sectors, particularly in the case where the quality of domestically made products is inferior compared to the quality of foreign ones. Finally, healthy competition in a particular market is stifled in this way.

Therefore, there is a dilemma in terms of the justifiability of shifting demand from foreign to domestic products. The author of the paper disagrees with this practice since it directly leads to consumer ethnocentrism, which is actually the consumer's orientation towards buying domestically made products. T. Shimp (1984) is among the authors who were the first to identify and deal with this phenomenon. His research has made a significant contribution to clarifying the complex nature of consumer ethnocentrism and has encouraged many authors throughout the world to focus their research studies on identifying its key antecedents. He defines consumer ethnocentrism as citizens' belief that products made in their native countries are superior to foreign ones. Accordingly, ethnocentric consumers are more likely to buy domestically made products. Research findings show that many such consumers believe that buying domestically produced products is a patriotic act and that this supports the growth of the national economy as well. According to them, the citizens who buy foreign products are largely responsible for economic problems in the native country, especially for the growth of unemployment (Good \& Huddleston, 1995).

The aforementioned arguments have contributed to the growing interest in studying consumer ethnocentrism at the global level. Today, this phenomenon attracts the attention of macroeconomists, particularly in terms of analyzing the cost-effectiveness of the „Buy domestic products" type of promotional campaigns.
The dilemma "for and against promoting the buying of domestic products" is the subject matter of numerous debates, considered in an attempt to answer the question whether or not this strategy really mitigates the effects of the financial crisis and protects citizens' jobs. Another question must also be posed: do these measures produce only short-term effects, particularly where domestic products are inferior to foreign ones in terms of their quality? Could it be that in this way the longterm development of the national economy is in fact jeopardized? Consumer ethnocentrism is a very interesting concept also from the point of view of marketing research. Accordingly, marketing researchers are particularly interested in finding an adequate methodology to measure consumers' ethnocentric tendencies and to also determine the degree to which consumer ethnocentrism is present among citizens of different countries. Measuring and comparing the levels of consumers' general ethnocentric tendencies across different regions of a single country is an important issue, too. Currently, marketing research is generally oriented towards a modeled approach to measuring consumer ethnocentrism, with the intention of designing research models marked by respective clearly identified key antecedents.

The concept of consumer ethnocentrism, i.e. its analysis and clarification, including its potential antecedents and the measurement methodology, is the objective of this study. The studies of consumer ethnocentrism are, by their nature, very specific since they include different sociological and marketing, as well as macro-economic components. In this respect, finding an adequate methodological solution to measuring consumer ethnocentric tendencies is a challenging task. For more than three decades now, researchers from many countries have been trying to design new and improve the existing scales to measure consumer ethnocentrism. This is a very important research activity since consumer ethnocentric tendencies can have significant social and economic implications. 
Therefore, this paper aims to investigate the effect that animosity towards the EU and patriotism may have on the overall level of consumer ethnocentrism. In addition, the paper examines whether the intensity of Serbian consumers' ethnocentric tendencies is higher than the level of their patriotism and animosity towards the EU.

A survey was used as a primary data collection method. As far as the statistical analysis is concerned, reliability analysis and confirmatory factor analysis - CFA (in order to assess the internal consistency and to construct the validity of the model) were applied, as well as the structural equation modeling that was used so as to test the effect of patriotism and animosity on consumer ethnocentrism. In addition to that, by applying the paired t-test, the (non)existence of the statistically significant differences in the respondents' attitudes regarding the three analyzed model variables was determined.

The paper is organized in five sections. Following the Introduction Section, the paper continues with the Literature Review Section, which deals with the concepts of consumer ethnocentrism, patriotism and animosity and their mutual relationships. The research hypotheses to be tested are set out in the concluding part of this section, in line with the results of the previous research. The third section explains the methodology of the research, as well as the structure of the sample. The fourth section contains the results of the empirical study, whereas the fifth section points to the conclusions and contributions of the paper, identifies the limitations of the present research and suggests the directions for future research.

\section{LITERATURE REVIEW}

\section{The Concept of Consumer Ethnocentrism}

Prior to the analysis of consumer ethnocentrism, it is necessary to address a broader concept of ethnocentrism. Ethnocentrism is a sociological concept fundamental to the study of the related concept - consumer ethnocentrism. By its nature, however, consumer ethnocentrism is not only a sociological concept, but it also has an economic aspect, which attracts the attention of sociologists, macroeconomists and marketing researchers. The first formal definition of ethnocentrism was formulated by W. G. Sumner (1906), and according to his definition, ethnocentrism is a view in which one's own group is the center of everything, whereas all others are scaled and rated with reference to it (Shankarmahesh, 2006). In this respect, ethnocentric individuals believe their group is superior to others and their system of values, attitudes and behaviors as well. Ethnocentrism does not only necessarily apply to national, religious or racial groups; it can also occur in small social groups, such as families. Simply put, ethnocentrism is an integral part of human nature.

Scientists' interest in studying ethnocentrism has led to the expansion of the field of the existing analysis and the introduction of a new concept, named consumer ethnocentrism. As previously stated, ethnocentric consumers are largely oriented towards purchasing domestic products. Consumer ethnocentrism is based on the view that imports harm the national economy and can cause numerous economic problems; on the other hand, buying domestic products is considered not only as an economic, but also as an ethical issue (Shimp \& Sharma, 1987).

Due to its complex nature and its social implications, consumer ethnocentrism is an important field of cultural and economic research (Maričić, 2011). Assessing a nation's degree of consumer ethnocentrism is very important for export-oriented companies, especially when planning to enter the international market. However, it should be noted that a high level of a nation's ethnocentrism does not necessarily imply that members of a particular nation exhibit a high level of consumer ethnocentrism. For example, the results of a study 
indicated that India's citizens were ethnocentric and showed a high degree of patriotism; however, they were also shown to be open to buying foreign products (Deb \& Chaudhuri, 2014). The relationship between cultural openness and consumer ethnocentrism is a source of disputes among many authors. The results of certain studies identified a negative (inverse) correlation between these two phenomena (Deb \& Sinha, 2016; Prince, Davies, Cleveland \& Palihawadana, 2016), on the one hand, whereas on the other, some researchers indicated that consumers' favorable attitudes towards other cultures and their values were not correlated with ethnocentric tendencies (Vida, Dmitrovic \& Obadia, 2008).

By analyzing the results of the existing studies, M. Shankarmahesh (2006) provides us with a detailed list of the antecedents and consequences of consumer ethnocentrism. Antecedents in this respect generally include socio-psychological factors (cultural openness, patriotism, conservatism, collectivism, animosity, a list of values), as well as economic factors (the stage of a country's economic development), political factors (political propaganda and leader manipulation) and demographic factors (gender, age, education, income). The main consequence of consumer ethnocentrism is the consumer's intention to buy domestic products, i.e. their unwillingness to buy foreign products.

A. T. Shimp and S. Sharma (1987) developed the most acclaimed scale to measure consumer ethnocentrism. This is the CETSCALE (Consumer Ethnocentric Tendencies Scale), commonly used by many researchers worldwide today. The scale consists of the 17 items that a respondent evaluates by specifying his/her level of agreement or disagreement with a particular item on the scale ranging from 1 to 7 . This means that when applying this scale, the highest possible score, i.e. the level of consumer ethnocentrism, is 119, which signifies the consumer's absolute orientation towards purchasing domestic products. On the other hand, the lowest ethnocentricity score is 17. In addition to the original CETSCALE, some researchers use modified CETSCALEs to measure consumer ethnocentric tendencies and these scales usually contain a smaller number of items (Vida, Dmitrovic \& Obadia, 2008). In addition, consumers' ethnocentric tendencies do not necessarily need to be measured within the 17-119 range, or on a 1-7 point scale; 5-point or 9-point scales can be used as well. It is important to note that besides the mentioned CETSCALE, there are other scales used for measuring consumer ethnocentrism. Among these scales, NATID (National Identity Scale) is most frequently used; however, it primarily measures the national identity, whereas consumer ethnocentrism makes one of its four dimensions (Veljković, 2009).

The measurement results show that the level of consumer ethnocentrism varies among different nations. The study conducted by A. O'Cass and K. Lim (2002) produced interesting results: it showed that the level of consumer ethnocentrism in Moscow was lower than the levels of consumer ethnocentrism in three US cities (Los Angeles, Denver and Detroit). The results of this study indicate that the citizens residing in Detroit show significantly higher levels of consumer ethnocentrism in relation to the residents of Los Angeles. This result is logical due to the fact that the American automobile industry is located in Detroit, whereas the population of Los Angeles consists of many nations. In terms of the results of the studies conducted in the territory of the Republic of Serbia, Central Serbia shows the highest level of consumer ethnocentrism, and is followed by Belgrade, whereas the lowest level of consumer ethnocentrism is identified in A. P. Vojvodina. In addition, as household income increases, the tendency to buy domestic products decreases (Veljković, 2009). The rural population generally shows a higher level of consumer ethnocentrism than the urban, which is also the case with the older population in comparison to the young (Marinković, Stanišić \& Kostić, 2011). 


\section{Implications of the Animosity and Patriotism in Terms of Consumer Ethnocentrism}

Animosity implies strong emotions based on the position that it is immoral and unethical to buy products that originate from an offending country (Klein, Ettenson \& Morris, 1998). Animosity towards a particular country is usually influenced by military, political or economic events (Deb \& Chaudhuri, 2014). Animosity is an emotion that conditions consumers' buying decisions. This implies consumers' unwillingness to buy a product from a particular country that is perceived as the offending country, independently of consumers' judgments about the quality of the products originating from that particular country. Therefore, consumers may have a positive attitude towards the quality of the products produced in a particular country, but due to their animosity towards that particular country they are unwilling to buy these products (Fernández-Ferrín, Bande-Vilela, Klein \& del Río-Araújo, 2015; Cheah, Phau, Kea \& Huang, 2016). It is important to note that there are disagreements among the authors over this particular issue since the findings obtained in some studies show that animosity may also affect product judgments, as well as purchasing decisions (Lee \& Lee, 2013).

The position that there are two distinctive categories of animosity - war animosity and economic animosity - is generally accepted in literature (Klein, Ettenson \& Morris, 1998). Thus, hostility towards a particular country is either the result of the military operations that particular country has implemented in other countries or the result of the economic policy of that particular country. This traditional concept was further expanded by E. B. Nes, R. Yelkur and R. Silkoset (2012), who identify the four dimensions of animosity: war animosity, economic animosity, political animosity and people animosity. The majority of research models chose to observe animosity as a single variable despite its identified multidimensional character.
The study of animosity is very important for marketing research since it may constitute a significant antecedent of consumer ethnocentrism, willingness to buy and purchasing choices. Animosity and consumer ethnocentrism can be analyzed as the variables of a specific research model. These variables do have certain similarities; however, the essential difference is that animosity relates to the assessment of how justifiable it is to buy foreign products because of some past events, whereas consumer ethnocentrism is related to a preference for domestic products over foreign ones (Cui, Wajda \& Hu, 2012). The results of the previous research show that animosity has a positive statistically significant effect on consumer ethnocentrism (Deb \& Chaudhuri, 2014). The positive effect of consumer ethnocentrism and animosity towards foreign products was also confirmed in a study conducted by Z. Ahmed, R. Anang, N. Othman and M. Sambasivan (2013). Similarly, animosity has a negative effect on the purchase of foreign products (Rose, Rose \& Shoham, 2009; Huang, Phau \& Lin, 2010).

In accordance with the review of relevant literature and the analysis of the geographical, economic and political situation of the Republic of Serbia, the author of this study decided to analyze the economic dimension of animosity, more precisely animosity towards the EU economic policy. In this respect, the first research hypothesis is defined as follows:

H1: Animosity towards the European Union influences Serbian consumers' orientation towards buying domestic products.

Patriotism can be defined as love of one's own country and one's concern for the well-being of their country, as well as the level of one's identification with one's nation and its symbols (Burns, 1997). Patriotism is also understood to depend on the two different perceptions of the sense of belonging to one's nation: instrumental and sentimental attachment (Meier-Pesti \& Kirchler, 
2003). Instrumental attachment implies the benefits that a person can gain as a member of a certain nation. The best example of this type of attachment is the citizenship that defines a person as being a member of a particular nation. In this context, it can be concluded that this type of attachment is based on a person's rational reasoning. Sentimental attachment develops in situations where personal values coincide with national ones. This type of attachment is of emotional nature and stems from cultural heritage, tradition and one's dedication to national symbols. According to the work by K. Meier-Pesti and E. Kirchler (2003), sentimental attachment has a stronger effect on the overall level of patriotism than instrumental attachment, although both effects are statistically significant.

Relevant literature distinguishes between the concept of nationalism and the concept of patriotism. Generally, both terms are related to a positive identification with a particular nation. However, nationalism implies the superiority and domination of one nation over others. On the other hand, patriotism as love of one's country does not imply national dominance (van der Toorn, Nail, Liviatan \& Jost, 2014). While patriotism is based on emotional attachment to one's own nation, nationalism discriminates members of other nations. Patriotism also involves a comparison of the quality of one's life with the value system of the nation which they belong. On the other hand, nationalism involves comparing the social values of two or more nations, where members of one nation devalue the values of other nations.

Patriotism evokes a sense of pride in a person and affection for domestically made products; such affection may arise from emotional attachment and can also be related to the intangible elements of quality. The study conducted by I. Vida and J. Reardon (2008) confirms a statistically significant effect of patriotism on consumer ethnocentrism and the purchase of domestic products. Citizens, who consider themselves to be patriots, usually prefer domestic products to foreign ones (Han, 1988). In accordance with the aforementioned facts, the second research hypothesis is formulated as follows:

H2: The patriotism of the citizens of the Republic of Serbia has positive impacts on consumer ethnocentrism.

\section{METHOD}

The primary objective of the study is to examine the effects of animosity towards the EU and the patriotism of the citizens of the Republic of Serbia on consumer ethnocentrism. Based on such a definition of the objective, it is clear that the proposed research model contains two independent variables (animosity and patriotism) and one dependent variable (consumer ethnocentrism). In addition to this, each of these variables is measured by a series of statements, which is the method commonly used in field marketing research (Table 1). The statements were formulated based on relevant marketing literature (Kosterman \& Feshbach, 1989; Vida, Dimitrijevic \& Obadia, 2008; Rose, Rose \& Shoham, 2009; Ahmed et al, 2013). The respondents were asked to indicate their agreement about or disagreement over the statements on the seven-point Likert scale, where score 1 indicates strong disagreement, whereas score 7 signifies strong agreement.

The personal interview method was used for data collection. The research was conducted in six cities in the territory of Central Serbia during 2015. A total of 221 questionnaires were completed by the respondents. The analysis of the demographic profile of the sample shows that women are represented in a slightly higher percentage compared to men, i.e. $57 \%$ of the respondents are women and $43 \%$ are men. The younger respondents (aged 18-31) account for $29.4 \%$ of the 
Table 1 Model variables and statements

\begin{tabular}{|c|c|}
\hline Model variables & Statements \\
\hline $\begin{array}{l}\text { Consumer } \\
\text { ethnocentrism }\end{array}$ & $\begin{array}{l}\text { S1: Serbian products first and foremost. } \\
\text { S2: We should buy products made in Serbia instead of letting other countries become rich } \\
\text { at our expense. } \\
\text { S3: Buying Serbian products is always the best choice. } \\
\text { S4: It may cost me more in the long run; however, I prefer buying Serbian products. }\end{array}$ \\
\hline Patriotism & $\begin{array}{l}\text { S1: I am proud to be a citizen of Serbia. } \\
\text { S2: I am emotionally attached to Serbia and everything that happens in it concerns me to a } \\
\text { great extent. } \\
\text { S3: I am proud to live in Serbia. } \\
\text { S4: I am proud to see the national flag wavering. }\end{array}$ \\
\hline $\begin{array}{l}\text { Animosity towards the } \\
\text { EU }\end{array}$ & $\begin{array}{l}\text { S1: One should be careful when dealing with EU companies. } \\
\text { S2: EU companies are not reliable trading partners. } \\
\text { S3: EU companies have a negative attitude towards Serbian companies. }\end{array}$ \\
\hline
\end{tabular}

Source: Author

sample. The middle-aged persons (32-45) are the largest demographic group and constitute $40.3 \%$ of the sample. The respondents aged 45 and older constitute $30.3 \%$ of the sample. The respondents are also classified according to their education level. In this respect, the sample mostly contains highly educated respondents $(44.3 \%)$. The respondents who completed secondary education account for $36.2 \%$ of the sample. The persons with a college degree take a share of $19.5 \%$ of the sample.

The data were analyzed by using the SPSS and Amos software. For the purpose of determining statistically significant differences in the levels of animosity, patriotism and consumer ethnocentrism, a Paired t-test was applied. The reliability and validity of the research model were tested by the CFA. The structural equation model was used to test the statistical significance and the magnitude of the effect of animosity and patriotism on consumer ethnocentrism.

\section{RESULTS}

In the first step of the statistical analysis, the arithmetic means and standard deviations for all of the three observed variables (consumer ethnocentrism, patriotism and animosity) were calculated. In addition, the average values for each of these variables were determined for all the respondents based on their evaluation of the questionnaire's statements. Then, the arithmetic means were calculated for all the three variables in terms of the total sample. The paired t-test was applied so as to find out whether there were statistically significant differences between the values of the arithmetic means of the two observed variables. This test shows whether the average values of the answers to the two specified questions are equal or whether they vary from one another, where the respondents evaluate these questions on the same measurement scale (Soldić-Aleksić i Chroneos-Krasavac, 2009). 
The results of the paired t-test indicate that there is a significantly higher level of patriotism in the sample in relation to the intensity of consumer ethnocentrism and animosity towards the EU (Table 2). On the other hand, the sample does not show any differences between the general level of consumer ethnocentrism and animosity towards the EU ( $p=0.865>0.05)$ Based on the results of the paired t-test, as well as the respondents' subjective perceptions, it is evident that they express a high level of patriotism and the moderate levels of consumer ethnocentrism and animosity. In general, in terms of the seven-point scales, the values of the arithmetic means that exceed 5 can be considered as high values for all constructs. On the other hand, the values lower than 3 can be characterized as low, whereas the values ranging from 3 to 5 are considered as moderate. The highest degree of the heterogeneity of the respondents' attitudes was identified for the consumer ethnocentrism variable $(\mathrm{SD}=1.55)$.

In the second step of the statistical analysis, the reliability of the three observed variables, as well as the internal consistency of the statements used for their measurement, were assessed. Reliability analysis usually implies the calculation of Cronbach's alpha. The minimum acceptable value of Cronbach's alpha is 0.7 for each variable
(Nunnally, 1978). All of the three variables fulfilled this reliability condition. Consumer ethnocentrism shows the highest reliability level (Cronbach's alpha $=0.93$ ). Furthermore, the other two variables are also characterized by the high level of reliability (patriotism: Cronbach's alpha $=0.89$; animosity: Cronbach's alpha $=0.80$ ).

Since this study implies the testing of the effects of patriotism and animosity on consumer ethnocentrism, it is only logical that the proposed research model contains two independent variables and one dependent. The accepted practice is to assess the validity of the model prior to testing the effects. With this in mind, the CFA was applied. This analysis includes a series of tests and calculations of a number of indices based on which the validity of the research model is determined (RFI - the relative fit index; NFI - the normed fit index; GFI - the goodness-of-fit index, CFI - the comparative fit index, TLI - the Tucker-Lewis index; IFI - the incremental fit index; RMSEA - the root mean square error of approximation; AVE - the average variance extracted; $\mathrm{CR}$ - composite reliability).

The results of the CFA are shown in Table 3. Based on the data presented, all the obtained values of the indices are considered to be satisfactory. The ratio of $\chi^{2} / \mathrm{df}$ is lower than 3 , which is the set threshold value (Byrne, 1998). The values of the RFI, NFI,

Table 2 The results of the paired t-test

\begin{tabular}{l|ccccc}
\hline \multicolumn{1}{c|}{ Variable } & Arithmetic mean & Standard deviation & $\mathrm{t}$ & $\mathrm{df}$ & $\mathrm{p}$ \\
\hline Consumer ethnocentrism & 4.32 & 1.55 & $-10.038^{*}$ & 220 & 0.000 \\
Patriotism & 5.23 & 1.40 & 1.55 & & \\
\hline Consumer ethnocentrism & 4.32 & 1.42 & $-0.170^{\mathrm{ns}}$ & 220 & 0.865 \\
Animosity & 4.33 & 1.40 & & \\
\hline Patriotism & 5.23 & 1.42 & $8.961^{*}$ & 220 & 0.000 \\
Animosity & 4.33 & & & \\
\hline
\end{tabular}

Note: ${ }^{*}$ The result is significant at the 0.01 level; ${ }^{\text {ns }}$ The result is not statistically significant.

Source: Author 
GFI, CFI, TLI and IFI indices are approximately equal to or exceed the threshold value of 0.9 (Hair, Black, Babin, Anderson \& Tatham, 2006), whereas the value of the RMSEA index is lower than the threshold value of 0.1 (Steiger, 1990). The AVE values of all of the three variables exceed the threshold of 0.5 (consumer ethnocentrism: AVE = 0.77; patriotism: $\mathrm{AVE}=0.67$; animosity: $\mathrm{AVE}=0.59$ ). Therefore, the model meets all the requirements in terms of convergent validity (Fornell \& Larcker, 1981). In addition, the CR coefficient values are higher than the threshold value of 0.7 for all of the three variables (consumer ethnocentrism: $C R=0.93$; patriotism: $C R=0.88$ animosity: $C R=0.81)$. It is important to note that all of the factor loadings are greater than 0.65 and at the 0.05 level of significance.

Table 3 The goodness-of-fit indices of the research

\begin{tabular}{c|cc}
\multicolumn{3}{c}{ model } \\
\hline $\begin{array}{c}\text { Goodness-of- } \\
\text { fit indices of } \\
\text { the model }\end{array}$ & $\begin{array}{c}\text { Recommended } \\
\text { values }\end{array}$ & Calculated values \\
\hline$\chi^{2} / \mathrm{df}$ & $<3$ & 2.90 \\
$\mathrm{RFI}$ & $>0.9$ & 0.91 \\
$\mathrm{NFI}$ & $>0.9$ & 0.93 \\
$\mathrm{GFI}$ & $>0.9$ & 0.91 \\
$\mathrm{CFI}$ & $>0.9$ & 0.96 \\
$\mathrm{TLI}$ & $>0.9$ & 0.94 \\
$\mathrm{IFI}$ & $>0.9$ & 0.96 \\
$\mathrm{RMSEA}$ & $<0.1$ & 0.09 \\
\hline
\end{tabular}

Source: Author

Following the testing of the validity of the model, the structural equation model (SEM) was applied in the final step of the statistical analysis. The SEM analysis was used in order to calculate the statistical significance and the magnitude of the effects of the two tested variables. The results of the SEM analysis are shown in Table 4. Both tested effects were statistically significant $(p<0.01)$. Thus, we can conclude that animosity towards the EU and patriotism expressed by the citizens of the Republic of Serbia are indicative of their orientation towards buying domestic products. This confirms both hypotheses formulated in this paper. However, based on the higher value of the $\beta$ coefficient, it is evident that patriotism stands out as a significant antecedent of consumer ethnocentrism. Obviously, love of one's country has a stronger effect on consumers' choices over buying domestically made products than antipathy towards the EU economic policy. The research findings indicate the fact that consumers may perceive foreign products as highquality ones, but because of the emotion of love for their home country, or anger towards the EU, some may decide to buy domestic products, despite their poorer quality.

Table 4 Hypothesis testing

\begin{tabular}{l|c}
\hline \multicolumn{1}{c|}{ Hypothesis } & $\begin{array}{c}\text { Standardized } \\
\beta \text { coefficient }\end{array} \quad$ Conclusion \\
\hline $\begin{array}{l}\text { H1: Animosity } \rightarrow \text { consumer } \\
\text { ethnocentrism }\end{array}$ & $0.341^{*} \quad$ Confirmed \\
$\begin{array}{l}\text { H2: Patriotism } \rightarrow \text { consumer } \\
\text { ethnocentrism }\end{array}$ & $0.456^{*} \quad$ Confirmed \\
* The result is significant at the 0.01 level $(p<0.01)$. \\
Source: Author
\end{tabular}

Finally, it is important to note that the independent variables describe the $48.4 \%$ of consumer ethnocentrism variability $(\mathrm{R} 2=0.484)$. Since this model contains only two independent variables, this percentage can be characterized as a very satisfactory one. The degree of linear correlation between the two observed variables is 0.517 , and this value is significant at the 0.05 level. It is evident that the degree of the linear correlation in the model is not high; therefore, multicollinearity does not represent a serious problem in this study. 
Multicollinearity was also tested by assessing the level of tolerance in terms of the observed independent variables and by analyzing the VIF (the variance inflation factor) values. Given the fact that the model contains two independent variables, the level of tolerance is 0.804 (which is significantly higher than 0.1), whereas the VIF value of 1.244 is lower than the threshold value of 5 (Field, 2000). This further confirms the low level of multicollinearity in the given research model, as well as the validity and reliability of the calculated values of the standardized coefficients.

\section{CONCLUSION}

The concept of consumer ethnocentrism has traditionally attracted the attention of economists and sociologists. Although researched over several decades, this issue is still relevant and engaging. Moreover, it can be concluded that its importance has been growing in recent years due to the effects of the global economic crisis. The economic crisis is perhaps the right time to encourage an ethnocentric behavior, or to point citizens in the direction of buying domestic products in order to strengthen domestic production and reduce unemployment. The implementation of this policy is especially characteristic of less-developed export-oriented economies.

Another factor giving importance to the study of consumer ethnocentrism and the identification of its antecedents is the rise of nationalism in many countries and increasing tensions in the world, which are not only of economic, but also of militaristic nature. The political crises in the North African countries, the tensions in the Middle East, the Kashmir conflict between India and Pakistan and the Russian military intervention in Syria are just some examples of the unstable economic situation in different regions and it is these occurrences that add to the importance of this study, primarily focused on testing the effects of patriotism and animosity on consumer ethnocentrism.
The above discussion points to the suitable choice of the model variables, especially concerning the current geopolitical situation, where the patriotism of many nations, as well as the animosity towards economic and/or military policies of certain countries, has been growing increasingly stronger. The contribution and originality of this paper are precisely reflected in this context, which is characterized not only by a strong economic dimension, but also by the social and political ones. However, it should be noted that there are a small number of the studies of consumer ethnocentrism in the Western Balkan Region. The special contribution of this research paper refers to the design of the research model, which has made it possible to analyze the antecedents of consumer ethnocentrism; thus, the paper is characterized by a pronounced marketing research dimension. Modern methods (CFA and SEM) are used in the research, which nowadays are considered as standard methods worldwide in terms of the similar types of field research.

Although the paper presents a relatively simple model that contains only two potential antecedents of consumer ethnocentrism, the choice of these variables makes a unique feature of the proposed model. In fact, patriotism is a very significant and frequently used variable in related cultural and economic research, particularly when identifying the magnitude of the effects of various factors on consumer ethnocentrism. On the other hand, researching the relationship between animosity and consumer ethnocentrism is a more recent topic. In a relatively small number of studies, researchers examine the impact of animosity on consumer ethnocentrism. Since this variable is rarely used in similar studies, its incorporation into the research model gives a distinctive contribution to the paper. In addition, if the papers where animosity is included in the research model as a variable are analyzed, it can be noted that the animosity of different countries/nations towards either the USA or the UK (Rose, Rose \& Shoham, 2009; Ahmed et 
al, 2013), as well as the animosity of Asian countries towards the economic policy of China or Japan (Huang, Phau \& Lin, 2010; Cui, Wajda \& Hu, 2012; Lee \& Lee, 2013) is usually analyzed in them. Although, generally, these types of studies examine the attitudes of Asian consumers (especially those from the Middle East and East Asia), there are also the studies that examine the animosity of European countries towards the economic policy of the USA or Germany (Riefler \& Diamantopoulos, 2007). However, as far as the author of this paper is aware of that, the animosity of the citizens of one European country towards the EU has this far not been studied.

The research findings confirm that the two independent variables (animosity and patriotism) stand out as the statistically significant antecedents of consumer ethnocentrism. Here, patriotism has a stronger effect on consumer ethnocentrism compared to animosity towards the EU. Consumers are primarily driven to buy domestically made products because of their emotion of love for their own country. On the other hand, antipathy towards the EU is also an important factor affecting Serbian consumers' purchasing decisions. This does not mean that consumers have a negative attitude towards the products that come from the EU; they feel animosity towards the economic policy of the European Union, which can influence them to buy domestic products. The results also confirm the presence of a high degree of patriotism and the moderate degrees of animosity and consumer ethnocentrism in the sample. Love of one's country among citizens is greater than their orientation towards purchasing domestic products. The lower level of consumer ethnocentrism in relation to patriotism indicates that, in spite of their love of their own country, some citizens prefer buying foreign products, probably because of the quality and branding of those products.

There are certain limitations to this study. Firstly, the research was carried out only once and it would be desirable that such research be conducted successively (on the same sample) in order to monitor changes in citizens' attitudes and behavior in relation to purchasing. Secondly, the study uses a simple research model that contains only two independent variables. It is desirable that future research models should contain a more complex set of variables. New models can be designed in order to additionally test the effects of nationalism, the national identity and cultural openness on consumer ethnocentrism. This would provide valuable and interesting results. Thirdly, the current research was conducted in the territory of one single country. The cross-cultural studies of consumer ethnocentrism would definitely provide a highly valuable input since that would provide an opportunity to compare the attitudes of different nations.

\section{REFERENCES}

Ahmed, Z., Anang, R., Othman, N., \& Sambasivan, M. (2013). To purchase or not to purchase US products: Role of religiosity, animosity, and ethno-centrism among Malaysian consumers. Journal of Services Marketing, 27(7), 551-563. doi: 10.1108/JSM-01-2012-0023

Berns, W. (1997). On patriotism. Public Interest, 127(2), 19-32.

Byrne, B. M. (1998). Structural equation modelling with LISREL, PRELIS, and SIMPLIS: Basic concepts, applications, and programming. Mahwah, NY: Lawrence Erlbaum.

Cheah, I., Phau, I., Kea, G., \& Huang, Y. A. (2016). Modelling effects of consumer animosity: Consumers' willingness to buy foreign and hybrid products. Journal of Retailing and Consumer Services, 30, May, 184-192. doi: 10.1016/j. jretconser.2016.01.018

Cui, A. P., Wajda, T. A., \& Hu, M. Y. (2012). Consumer animosity and product choice: Might price make a difference? Journal of Consumer Marketing, 29(7), 494-506. doi: $10.1108 / 07363761211275009$

Deb, M., \& Chaudhuri, H. R. (2014). Impact of firm's reputation and ethnocentrism on attitude towards foreign products. Marketing Intelligence \& Planning, 32(5), 646-664. doi: 10.1108/MIP-04-2013-0070 
Deb, M., \& Sinha, G. (2016). Impact of culture on religiosity, cosmopolitanism and ethnocentrism. Asia Pacific Journal of Marketing and Logistics, 28(1), 56-72. doi: 10.1108/ APJML-12-2014-0173

Fernández-Ferrín, P., Bande-Vilela, B., Klein, J. G., \& del Río-Araújo, M. L. (2015). Consumer ethnocentrism and consumer animosity: Antecedents and consequences. International Journal of Emerging Markets, 10(1), 73-88. doi: 10.1108/IJOEM-11-2011-0102

Field, A. (2000). Discovering statistics using SPSS for Windows. Sage Publication: Thousand Oaks.

Fornell, C., \& Larcker, D. F. (1981). Evaluating structural equation models with unobservable variables and measurement error. Journal of Marketing Research, 18(1), 39-50.

Good, K. L., \& Huddleston, P. (1995). Ethnocentrism of Polish and Russian consumers: Are feelings and intentions related? International Marketing Review, 12(5), 35-48. doi:10.1108/02651339510103047

Hair, Jr. J. F., Black, W. C., Babin, B., Anderson R., \& Tatham, R. (2006). Multivariate Data Analysis (6 $6^{\text {th }}$ ed.). Upper Saddle River, NY: Prentice Hall.

Han, C. M. (1988). The role of consumer patriotism in the choice of domestic versus foreign products. Journal of Advertising Research, 28(3), 25-32.

Huang, Yu-An, Phau, I., \& Lin, C. (2010). Consumer animosity, economic hardship, and normative influence: How do they affect consumers' purchase intention? European Journal of Marketing, 44(7/8), 909-937. doi: 10.1108/03090561011047463

Klein, J. G., Ettenson, R., \& Morris, M. D. (1998). The animosity model of foreign product purchase: An empirical test in the people's Republic of China. Journal of Marketing, 62(1), 89-100. doi: 10.2307/1251805

Kosterman, R., \& Feshbach, S. (1989). Toward a measure of patriotic and nationalistic attitudes. Political Psychology, 10(2), 257-274.

Lee, R., \& Lee, K. T. (2013). The longitudinal effects of a twodimensional consumer animosity. Journal of Consumer Marketing, 30(3), 273-282. doi: 10.1108/07363761311328946
Maričić, B. (2011). Ponašanje potrošača. Beograd, Republika Srbija: Ekonomski fakultet Univerziteta u Beogradu.

Marinković, V., Stanišić, N. i Kostić, M. (2011). Potrošački etnocentrizam građana Srbije. Sociologija 53(1), 43-58. doi: 10.2298/SOC1101043M

Meier-Pesti, K., \& Kirchler, E. (2003). Nationalism and patriotism as determinants of European identity and attitudes towards the euro. Journal of Socio-Economics, 32(6), 685-700. doi:10.1016/j.socec.2003.10.006

Nes, E. B., Yelkur, R., \& Silkoset, R. (2012). Exploring the animosity domain and the role of affect in a crossnational context. International Business Review, 21(5), 751765. doi:10.1016/j.ibusrev.2011.08.005

Nunnally, J. C. (1978). Introduction to Psychological Measurement. New York, NY: McGraw-Hill.

O'Cass, A., \& Lim, K. (2002). Understanding the younger Singaporean consumers' views of western and eastern brands. Asia Pacific Journal of Marketing and Logistics, 14(4), 54-79. doi: 10.1108/13555850210764954

Prince, M., Davies, M., Cleveland, M., \& Palihawadana, D. (2016). Here, there and everywhere: A study of consumer centrism. International Marketing Review, 33(5), 715-754. doi: 10.1108/IMR-06-2014-0205

Riefler, P., \& Diamantopoulos, A. (2007). Consumer animosity: A literature review and a reconsideration of its measurement. International Marketing Review, 24(1), 87119. doi: $10.1108 / 02651330710727204$

Rose, M., Rose, G. M., \& Shoham, A. (2009). The impact of consumer animosity on attitudes towards foreign goods: A study of Jewish and Arab Israelis. Journal of Consumer Marketing, 26(5), 330-339. doi: 10.1108/07363760910976583

Shankarmahesh, M. (2006). Consumer ethnocentrism: An integrative review of its antecedents and consequences. International Marketing Review, 23(2), 146-172. doi: 10.1108/02651330610660065

Shimp, T. A. (1984). Consumer ethnocentrism: The concept and preliminary test. Advances in Consumer Research, 11(1), 285-290.

Shimp, A. T., \& Sharma, S. (1987). Consumer ethnocentrism: Construction and validation of the CETSCALE. Journal of Marketing Research, 24(3), 280-289. doi: 10.2307/3151638 
Soldić-Aleksić, J., i Chroneos-Krasavac, B. (2009). justification motivation eliminate the liberalKvantitatione tehnike $u$ istraživanju tržišta. Beograd, conservative gap in patriotism? Journal of Experimental Republika Srbija: Ekonomski fakultet. Social Psychology, 54, 50-60. doi: 10.1016/j.jesp.2014.04.003

Steiger, J. H. (1990). Structural model evaluation and modification: an interval estimation approach. Multivariate Behavioral Research, 25(2), 173-180. doi: 10.1207/s15327906mbr2502_4

Sumner, W. G. (1906). Folkways: A study of the sociological importance of usages, manners, customs, mores, and morals. Boston, MA: Ginn and Company.

van der Toorn, J., Nail, P. R., Liviatan, I., \& Jost, J. T. (2014). My country, right or wrong: Does activating system

Veljković, S. (2009). Uticaj etnocentrizma na potrošače u Srbiji. Marketing, 40(2), 97-106.

Vida, I., Dmitrović, T., \& Obadia, C. (2008). The Role of ethnic affiliation in consumer ethnocentrism. European Journal of Marketing, 42(3/4), 327-343. doi: $10.1108 / 03090560810852968$

Vida, I., \& Reardon, J. (2008). Domestic consumption: rational, affective or normative choice? Journal of Consumer Marketing, 25(1), 34-44. doi: 10.1108/07363760810845390.

Received on $25^{\text {th }}$ January 2017, after one revision, accepted for publication on $24^{\text {th }}$ April 2017.

Published online on $28^{\text {th }}$ April 2017.

Veljko Marinkovic is an Associate Professor of Consumer Behavior and Marketing Research at the Faculty of Economics, University of Kragujevac, the Republic of Serbia. He holds PhD in Business Management, from the Faculty of Economics, University of Belgrade, the Republic of Serbia. His major interests are related to customer satisfaction and loyalty measurement, services marketing, consumer ethnocentrism. 


\title{
EFEKTI ANIMOZITETA PREMA EVROPSKOJ UNIJI I PATRIOTIZMA NA POTROŠAČKI ETNOCENTRIZAM GRAĐANA REPUBLIKE SRBIJE
}

\author{
Veljko Marinković* \\ Ekonomski fakultet Univerziteta u Kragujevcu
}

Ekonomske, političke i militarističke tenzije među državama prisutne su širom sveta. Pojačanoj nestabilnosti svetske ekonomije doprinosi i razorno dejstvo Globalne finansijske krize. Stiče se utisak da poslednjih godina među mnogim nacijama jača stepen patriotizma i nacionalizma, ali i animoziteta prema ekonomskoj ili vojnoj politici drugih zemalja. Upravo postojeća situacija u svetu je pogodna za usmeravanje građana ka kupovini domaćih proizvoda. Ovakva politika može biti korisna u slučaju manje razvijenih, uvozno orijentisanih ekonomija. Shodno navedenom, u uslovima ekonomske krize, na značaju dobijaju istraživanja potrošačkog etnocentrizma. U radu su testirani uticaji patriotizma građana Republike Srbije i animoziteta prema Evropskoj uniji na potrošački etnocentrizam. Rezultati su pokazali da se obe varijable ističu kao statistički značajne antecedente potrošačkog etnocentrizma, s tim što patriotizam ima jači uticaj na usmerenost potrošača ka kupovini domaćih proizvoda. Istraživački nalazi ukazuju da ljubav prema svojoj zemlji može preusmeriti izbor potrošača ka domaćim brendovima, uprkos pozitivnom imidžu i visokom kvalitetu inostranih brendova. Dodatno, zbog antipatije koju građani osećaju prema ekonomskoj politici Evropske unije, deo njih se može odlučiti za kupovinu manje kvalitetnih domaćih proizvoda, i pored činjenice da ovakvo ponašanje ne utiče negativno na sam stav o inostranim proizvodima.

Ključne reči: potrošački etnocentrizam, patriotizam, animozitet, kupovina domaćih proizvoda, konfirmativna faktorska analiza, model strukturalnih jednačina

JEL Classification: M31, M37

\section{UVOD}

Interesantno pitanje koje se može postaviti kreatorima ekonomske politike jedne države glasi: Da li je poželjno da vlada podstiče usmerenost građana

* Korespondencija: V. Marinković, Ekonomski fakultet Univerziteta u Kragujevcu, Đ. Pucara 3, 34000 Kragujevac, Republika Srbija; e-mail: vmarinkovic@kg.ac.rs ka kupovini domaćih proizvoda i da li ovakve mere imaju pozitivan uticaj na razvoj nacionalne ekonomije? S jedne strane, usmerevanje potrošača ka domaćim proizvodima može doprineti rastu domaće proizvodnje i zaposlenosti, naročito u uslovima ekonomske krize i u slučaju manje razvijenih i uvozno orijentisanih zemalja. S druge strane, može se postaviti i pitanje opravdanosti usmeravanja građana 
ka nedovoljno kvalitetnim domaćim proizvodima. Da li se ovakav pristup može podjednako sprovoditi u različitim delatnostima, naročito u slučaju kada su po kvalitetu domaći proizvodi inferiorniji od inostranih. Osim toga, ovim putem se ograničava i zdrava konkurentska utakmica na određenom tržištu.

Ostaje dilema u pogledu ispravnosti skretanja tražnje sa inostranih ka domaćim proizvodima. Ova dilema vodi nas ka pojmu potrošačkog etnocentrizma, koji se odnosi na usmerenost građana ka kupovini domaćih proizvoda. Jedan od tvoraca ovog fenomena, koji je u svojim istraživanjima dao značajan doprinos rasvetljavanju kompleksne prirode potrošačkog etnocentrizma, ali i podstakao brojne autore širom sveta da fokusiraju svoja istraživanja ka identifikaciji njegovih ključnih pokretača je T. Schimp (1984), koji definiše potrošački etnocentrizam kao uverenje građana da su domaći proizvodi superiorniji od inostranih. Shodno tome, etnocentrični potrošači su u većoj meri usmereni ka kupovini domaćih proizvoda. Rezultati sprovedenih istraživanja pokazuju da mnogi među njima smatraju da je kupovina domaćih proizvoda patriotski čin, ali i potez koji pomaže napredak domaće ekonomije. Po njihovom mišljenju, građani koji kupuju inostrane proizvode su u velikoj meri odgovorni za ekonomske probleme u svojoj zemlji, a posebno za rast nezaposlenosti (Good \& Huddleston, 1995).

Prethodno iznete tvrdnje doprinele su afirmaciji izučavanja potrošačkog etnocentrizma. Danas ovaj fenomen zaokuplja pažnju makroekonomista, naročito u pogledu ispitivanja isplativosti sprovođenja promotivnih kampanja koje nose naziv: „Kupujmo domaće“. Dilema „za i protiv potenciranja kupovine domaćih proizvoda" predmet je brojnih rasprava sa ciljem dobijanja odgovora na pitanje da li se ovim putem zaista ublažava dejstvo finansijske krize i da li se štite radna mesta građana. Ili su ove mere samo kratkoročnog karaktera u situacijama kada domaći proizvodi zaostaju po kvalitetu u odnosu na inostrane? Možda se ovim putem, zapravo, posmatrano na dugi rok, ugrožava razvoj nacionalne ekonomije. Potrošački etnocentrizam je interesantan pojam i sa aspekta marketing istraživanja. U tom kontekstu, istraživači marketinga su naročito zainteresovani za pronalaženje adekvatne metodologije merenja potrošačkog etnocentrizma, kao i za utvrđivanje stepena $\mathrm{u}$ kojem je on prisutan među građanima različitih država. Osim navedenog, prisutna su i poređenja stepena opšteg potrošačkog etnocentrizma među različitim regionima jedne države. Danas je $\mathrm{u}$ marketingu veoma prisutan i modelirani pristup merenja potrošačkog etnocentrizma, sa namerom koncipiranja istraživačkih modela koji pokazuju koje se varijable ističu kao njegove ključne antecedente.

Predmet istraživanja ovog rada je koncept potrošačkog etnocentrizma, odnosno, njegovo pojmovno objašnjenje, ukazivanje na metodologiju merenja i razmatranje njegovih potencijalnih pokretača. Istraživanja potrošačkog etnocentrizma su, po svojoj prirodi, specifična, budući da ona poseduju različite sociološke, marketinške, kao i makroekonomske komponente. U tom smislu, pronalaženje adekvatnog metodološkog rešenja za merenje potrošačkog etnocentrizma je izazovan zadatak. Više od tri decenije istraživači iz brojnih zemalja pokušavaju da koncipiraju nove i unaprede postojeće skale za merenje potrošačkog etnocentrizma. Reč je o važnoj istraživačkoj aktivnosti, budući da potrošački etnocentrizam može imati značajne društvene i ekonomske implikacije.

Cilj rada je ispitivanje uticaja koji animozitet prema Evropskoj uniji (EU) i patriotizam mogu imati na opšti stepen potrošačkog etnocentrizma. Osim navedenog, $\mathrm{u}$ radu se ispituje i da li je intenzitet potrošačkog etnocentrizma građana Republike Srbije (RS) viši u odnosu na stepen njihovog patriotizma i animoziteta prema EU.

Kada je reč o korišćenoj metodologiji, primarni podaci su prikupljeni primenom anketnog metoda. Od statističkih analiza korišćene su analiza pouzdanosti i konfirmativna faktorska analiza (u cilju procene interne konzistentnosti konstatacija i validnosti modela), kao i model strukturalnih jednačina, koji je omogućio testiranje uticaja animoziteta i patriotizma na potrošački etnocentrizam. Osim navedenog, primenom uparenog $\mathrm{t}$ testa utvrđeno je (ne)postojanje statistički značajnih razlika u stavovima ispitanika $\mathrm{u}$ pogledu tri analizirane varijable modela. 
Rad se sastoji iz pet sekcija. Posle uvoda, rad sadrži pregled literature $\mathrm{u}$ kojem su analizirani koncepti potrošačkog etnocentrizma, patriotizma i animoziteta, kao i njihovi međusobni odnosi. Na kraju ove sekcije, shodno rezultatima prethodnih istraživanja, formulisane su istraživačke hipoteze, koje su kasnije testirane $\mathrm{u}$ funkciji njihovog potvrđivanja, odnosno odbacivanja. U trećoj sekciji je objašnjena metodologija sprovedenog istraživanja, kao i struktura uzorka. Cetvrta sekcija sadrži rezultate empirijske studije, dok su u petoj sekciji dati zaključci i doprinos rada, ali je ukazano i na ograničenja, kao i na pravce budućih istraživanja.

\section{PREGLED LITERATURE}

\section{Koncept potrošačkog etnocentrizma}

Pre analize potrošačkog etnocentrizma, potrebno je da se objasni širi koncept koji nosi naziv etnocentrizam. Etnocentrizam je koncept sociološkog karaktera koji je predstavljao temelj za proučavanje njemu srodnog koncepta potrošačkog etnocentrizma. Ipak, potrošački etnocentrizam, po svojoj prirodi, nije samo sociološki koncept, nego sadrži i ekonomsku dimenziju, zbog čega je predmet pažnje, sociologa, makroekonomista i istraživača marketinga. Prema prvoj formalnoj definiciji etnocentrizma (Sumner, 1906), reč je o pogledu na stvari od strane pripadnika jedne grupe po kojem je njihova grupa u centru svega, dok su sve ostale grupe njoj podređene (Shankarmahesh, 2006). S tim u vezi, etnocentrični građani smatraju svoju grupu superiornom, kao i njen sistem vrednosti, stavova i ponašanja. Etnocentrizam se ne mora odnositi samo na nacionalne, verske ili rasne grupe, nego može biti usmeren i ka manjim društvenim grupama, kao što su porodice. Jednostavno rečeno, etnocentrizam je sastavni deo ljudske prirode.

Interesovanje za proučavanje etnocentrizma, dovelo je do produbljivanja postojeće analize i uvođenja novog koncepta koji nosi naziv potrošački etnocentrizam. Etnocentrični potrošači su $\mathrm{u}$ većoj meri usmereni ka kupovini domaćih proizvoda. Potrošački etnocentrizam se temelji na stavu da uvoz šteti domaćoj ekonomiji, i da može prouzrokovati brojne ekonomske probleme, ali i da je kupovina domaćih proizvoda, ne samo ekonomsko, već i etičko pitanje (Shimp \& Sharma, 1987).

Zbog svoje prirode i kompleksnih društvenih implikacija, potrošački etnocentrizam je važno područje kulturoloških i ekonomskih istraživanja (Maričić, 2011). Ispitivanje stepena potrošačkog etnocentrizma jedne nacije je važno za izvozno orijentisana preduzeća, u situacijama kada se planira ulazak na određeno inostrano tržište. Pri tome, treba znati da visok stepen etnocentrizma jedne nacije ne znači nužno da će pripadnici date nacije ispoljiti i visok nivo potrošačkog etnocentrizma. Rezultati istraživanja pokazuju da su građani Indije etnocentrični i da poseduju visok stepen patriotizma, ali da su istovremeno otvoreni za kupovinu inostranih proizvoda (Deb \& Chaudhuri, 2014). Odnos kulturološke otvorenosti i potrošačkog etnocentrizma izaziva nesuglasice među brojnim autorima. Naime, rezultati pojedinih studija ukazuju na inverznu povezanost ove dve pojave (Deb \& Sinha, 2016; Prince, Davies, Cleveland \& Palihawadana, 2016) dok, s druge strane, pojedini istraživači su pokazali da povoljan stav prema drugim kulturama i njihovim vrednostima nije $u$ vezi sa etnocentričnim tendencijama datih potrošača (Vida, Dmitrovic \& Obadia, 2008).

Analizom rezultata prethodnih studija, M. Shankarmahesh (2006) daje detaljnu listu pokretača i posledica potrošačkog etnocentrizma. Kada je reč o pokretačima, njih čine prvenstveno socio-psihološki faktori (kulturološka otvorenost, patriotizam, konzervativizam, kolektivizam, animozitet, liste vrednosti), ali i ekonomski faktori (razvijenost privrede jedne zemlje), politički faktori (propaganda i manipulacije lidera), kao i demografski faktori (pol, starost, obrazovanje, dohodak). Glavna konsekvenca potrošačkog etnocentrizma je namera kupovine domaćih proizvoda, odnosno, izbegavanje kupovine inostranih proizvoda.

A. T. Shimp i T. Sharma (1987) su kreirali najpoznatiju skalu za merenje potrošačkog etnocentrizma. Reč je o 
CET skali (Consumer Ethnocentric Tendency Scale - skala za merenje etnocentričnih tendencija) koja je danas često korišćena. Skala obuhvata 17 pitanja, odnosno, konstatacija, a ispitanici iskazuju stepen slaganja sa ovim konstatacijama $u$ intervalu 1-7. To znači da primenom ove skale najviši stepen potrošačkog etnocentrizma iznosi 119, i on označava potpunu usmerenost ka kupovini domaćih proizvoda. S druge strane, najniži stepen etnocentričnosti iznosi 17. Osim izvorne CET skale, pojedini istraživači u svojim studijama etnocentrizam mere ne preko svih 17 pitanja, već preuzimaju samo manji broj konstatacija (Vida, Dmitrovic \& Obadia, 2008). Takođe, nije nužno da se stepen etnocentrizma kreće u rasponu 17119, ili u rasponu 1-7, budući da se mogu koristiti i petostepene ili na primer, devetostepene skale. Važno je istaći da od ostalih skala koje se koriste za merenje potrošačkog etnocentrizma, među poznatije spada tzv. NATID skala (The National Identity Scale) koja je, u stvari, skala za merenje nacionalnog identiteta, pri čemu se, prema strukturi ove skale, potrošački etnocentrizam posmatra kao jedna od njegovih dimenzija (Veljković, 2009).

Rezultati merenja potrošačkog etnocentrizma pokazuju da njegov nivo varira među pripadnicima različitih nacija. Interesantne rezultate prikazuju A. O'Cass i K. Lim (2002), po kojima je nivo potrošačkog etnocentrizma u Moskvi niži u odnosu na nivo potrošačkog etnocentrizma $u$ tri grada SAD (Los Anđeles, Denver i Detroit). Rezultati ove studije pokazuju da je stanovništvo Detroita u znatno većoj meri potrošački etnocentrično u odnosu na stanovnike Los Anđelesa. Ovaj rezultat je logičan zbog činjenice da je američka automobilska industrija smeštena u Detroitu, dok je Los Anđeles grad u kojem dobar deo stanovništva čine manjine. Kada govorimo o rezultatima studija koje su sprovedene na teritoriji RS, najviši stepen potrošačkog etnocentrizma prisutan je u Centralnoj Srbiji, zatim, u Beogradu i na kraju u A. P. Vojvodini. Osim toga, porast prihoda domaćinstava imlicira pad potrošačkog etnocentrizma (Veljković, 2009). Viši nivo potrošačkog etnocentrizma pokazuje seosko u odnosu na gradsko stanovništvo, kao i stariji u odnosu na mlađe građane (Marinković, Stanišić \& Kostić, 2011).

\section{Odnos animoziteta i patriotizma prema potrošačkom etnocentrizmu}

Potrošački animozitet predstavlja snažno osećanje o tome da je nemoralno i neetički kupovati proizvode koji dolaze iz zemlje koja prema domaćoj zemlji ispoljava određeni vid neprijateljstva (Klein, Ettenson \& Morriset, 1998). Stvaranju animoziteta prema određenoj zemlji obično prethode vojni, politički ili ekonomski događaji (Deb \& Chaudhuri, 2014). Animozitet je jedan od osećaja koji utiče na donošenje odluka potrošača u procesu kupovine. Ovaj osećaj implicira izbegavanje kupovine proizvoda iz određene zemlje, pri čemu on ne utiče na potrošačevo negativno rasuđivanje o tim proizvodima. Time, potrošači mogu imati pozitivan stav o kvalitetu datih proizvoda, ali zbog antipatije koju osećaju prema zemlji njihovog porekla, oni izbegavaju kupovinu datih proizvoda (Fernández-Ferrín, BandeVilela, Klein \& del Río-Araújo, 2015; Cheah, Phau, Kea \& Huang, 2016). Ipak, važno je istaći da postoje nesuglasice među autorima i po ovom pitanju, budući da je u pojedinim studijama dokazano da animozitet može imati uticaj na rasuđivanje o samom proizvodu, a ne samo na kupovno ponašanje (Lee \& Lee, 2013).

U literaturi je prihvaćen stav da se mogu razlikovati dve ključne dimenzije animoziteta: ratni i ekonomski animozitet (Klein, Ettenson \& Morriset, 1998). Očito, bes prema određenoj zemlji je posledica ili vojnih operacija koje je ta zemlja sprovodila u drugim državama, ili je posledica njene ekonomske politike. Ovo tradicionalno gledište proširuju E. B. Nes, R. Yelkur i R. Silkoset (2012), koji izdvajaju četiri komponente animoziteta: ratni, ekonomski, politički i ljudski animozitet. U većini istraživačkih modela, uprkos identifikovanim dimenzijama, animozitet je posmatran kao jedinstvena varijabla.

Značaj ispitivanja animoziteta $\mathrm{u}$ marketingu odraz je činjenice da on može biti važna antecedenta potrošačkog etnocentrizma, spremnosti kupovine i izbora određenog proizvoda. Animozitet i potrošački etnocentrizam se mogu analizirati kao varijable određenog istraživačkog modela. Ove varijable imaju izvesne sličnosti, ali suštinska razlika je ta što se animozitet odnosi na procenjivanje opravdanosti 
kupovine inostranih proizvoda zbog nekih događaja iz prošlosti, dok se potrošački etnocentrizam vezuje za preferiranje domaćih $\mathrm{u}$ odnosu na inostrane proizvode (Cui, Wajda \& Hu, 2012). Rezultati ranije sprovedenih istraživanja pokazuju da animozitet ima pozitivan statistički značajan uticaj na potrošački etnocentrizam (Deb \& Chaudhuri, 2014). Pozitivan odnos potrošačkog etnocentrizma i animoziteta prema inostranim proizvodima potvrđen je i u studiji koju su sproveli Z. Ahmed, R. Anang, N. Othman i M. Sambasivan (2013). Slično, animozitet ima negativan efekat na kupovinu inostranih proizvoda (Rose, Rose \& Shoham, 2009; Huang, Phau \& Lin, 2010).

$\mathrm{U}$ skladu sa pregledom relevantne literature i sagledavanjem geografskog, ekonomskog i političkog položaja RS, opredeljenje autora ove studije je bilo da se varijabla animozitet veže za njegovu ekonomsku dimenziju i to prema ekonomskoj politici EU. U tom smislu, definisana je prva istraživačka hipoteza:

H1: Animozitet prema Evropskoj uniji implicira usmerenost građana Republike Srbije ka kupovini domaćih proizvoda.

Patriotizam se može definisati kao osećaj ljubavi, ili zabrinutosti pojedinca za njegovu zemlju, kao i stepen povezanosti pojedinca sa svojom nacijom i njenim simbolima (Berns, 1997). Patriotizam može obuhvatiti dva osećanja pripadnosti naciji: instrumentalnu i sentimentalnu pripadnost (MeierPesti \& Kirchler, 2003). Instrumentalna pripadnost podrazumeva koristi koje pojedinac može imati kao pripadnik određene nacije. Najbolji primer ove vrste pripadnosti je državljanstvo koje pojedinac stiče kao pripadnik date nacije. U tom kontekstu, može se konstatovati da se ova vrsta pripadnosti temelji na racionalnom razmišljanju pojedinca. Sentimentalna pripadnost se ispoljava u situacijama kada se lične vrednosti pojedinca podudaraju sa nacionalnim vrednostima. Ova pripadnost je emocionalnog karaktera i proističe iz kulturalnog nasleđa, tradicije i posvećenosti nacionalnim simbolima. Studija K. Meier-Pesti-a i E. Kirchler-a (2003), pokazala je da sentimentalna komponenta ima jači uticaj na opšti stepen patriotizma od instrumentalne komponente, uprkos statističkoj značajnosti oba efekta.
U literaturi je napravljenja razlika između pojmova nacionalizam i patriotizam. U celini, oba pojma se vezuju za pozitivnu identifikaciju sa određenom nacijom. Ipak, nacionalizam podrazumeva superiornost $\mathrm{i}$ dominaciju jedne $\mathrm{u}$ odnosu na druge nacije. S druge strane, patriotizam podrazumeva ljubav prema svojoj naciji bez direktnog poređenja sa drugim nacijama (van der Toorn, Nail, Liviatan \& Jost, 2014). Dok se patriotizam zasniva na emocionalnoj vezi sa sopstvenom nacijom, nacionalizam se zasniva na diskriminisanju pripadnika drugih nacija. Karakteristično za patriotizam je poređenje kvaliteta sopstvenog života sa sistemom vrednosti nacije kojoj on pripada. $S$ druge strane, nacionalizam podrazumeva poređenje društvenih vrednosti dve ili više nacija, pri čemu, $u$ ovom slučaju, pripadnici jedne nacije osporavaju vrednosti drugih nacija.

Patriotizam stvara u pojedincu osećaj ponosa i naklonost ka domaćim proizvodima, pri čemu se ova naklonost može bazirati na emocionalnoj privrženosti i na neopipljivim elementima kvaliteta. U studiji I. Vida i J. Reardon-a (2008), dokazan je statistički značajan uticaj patriotizma na potrošački etnocentrizam, kao i na kupovinu domaćih proizvoda. Građani koji sebe smatraju patriotama, obično favorizuju domaće u odnosu na inostrane proizvode (Han, 1988). Saglasno iznetim tvrdnjama, formulisana je druga istraživačka hipoteza:

H2: Patriotizam građana Republike Srbije ima pozitivan statistički značajan uticaj na opšti stepen potrošačkog etnocentrizma.

\section{METODOLOŠKI PRISTUP}

Osnovni cilj studije je ispitivanje uticaja animoziteta prema EU i patriotizma građana RS na potrošački etnocentrizam. Iz ovako formulisanog cilja, predloženi istraživački model sadrži dve nezavisne varijable (animozitet i patriotizam) i jednu zavisnu varijablu (potrošački etnocentrizam). Pri tome, svaka od navedenih varijabli je merena preko skupa korišćenih konstatacija, što je uobičajen pristup $\mathrm{u}$ terenskim marketing istraživanjima (Tabela 1). Konstatacije su 
preuzete na osnovu pregleda relevantne marketinške literature (Kosterman \& Feshbach, 1989; Vida, Dimitrijevic \& Obadia, 2008; Rose, Rose \& Shoham, 2009; Ahmed et al, 2013). Ispitanici su stepen slaganja sa datim konstatacijama iskazivali na sedmostepenoj Likertovoj skali. U tom smislu, ocena 1 označavala je apsolutno neslaganje, dok se ocena 7 odnosila na apsolutno slaganje ispitanika sa određenom konstatacijom.

Prikupljanje podataka je izvršeno tokom 2015. godine u šest gradova Centralne Srbije, tehnikom ličnog intervjua. Ukupno je prikupljen 221 kompletno popunjen upitnik. Analiza demografskog profila uzorka pokazuje da su u njemu žene zastupljene $\mathrm{u}$ većem procentu u odnosu na muškarce. Naime, uzorak sadrži 57\% žena i $43 \%$ muškaraca. Mlađih ispitanika (starosti 18-31 godine) ima 29.4\% u uzorku. $S$ druge strane, ispitanici srednjih godina (32-45) čine najbrojniju demografsku grupu i njih ima ukupno $40.3 \%$ u uzorku. Stariji ispitanici, koji imaju više od 45 godina, čine 30.3\% uzorka. Treći posmatrani kriterijum podele ispitanika je obrazovanje. Posmatrajući ovaj kriterijum, konstatuje se da uzorak najvećim delom sadrži visoko obrazovane ispitanike (44.3\%). Nakon toga, najbrojniju grupu čine ispitanici sa završenom srednjom školom - 36.2\% uzorka. Najmanje brojna obrazovna grupa u uzorku su ispitanici sa diplomom više škole, i oni čine $19.5 \%$ uzorka.

Analiza podataka sprovedena je u statističkim programima SPSS i Amos. U cilju utvrđivanja statistički značajnih razlika u stepenu animoziteta, patriotizma i potrošačkog etnocentrizma, primenjen je upareni $t$ test. Testiranje pouzdanosti i validnosti istraživačkog modela izvršeno je uz pomoć konfirmativne faktorske analize. $\mathrm{Za}$ ispitivanje statističke značajnosti i jačine uticaja animoziteta i patriotizma na potrošački etnocentrizam, korišćen je model strukturalnih jednačina.

\section{REZULTATI ISTRAŽIVANJA}

$\mathrm{Na}$ početku statističke analize, izračunate su aritmetičke sredine i standardne devijacije za sve tri posmatrane varijable (potrošački etnocentrizam, patriotizam i animozitet). Pri tome, za svakog pojedinačnog ispitanika su utvrđene prosečne vrednosti ovih varijabli na osnovu ocena koje su oni davali konstatacijama koje su upotrebljene za njihovo merenje. Nakon toga, izračunate su aritmetičke sredine za sve tri varijable na nivou ukupnog uzorka.

Tabela 1 Varijable modela i konstatacije

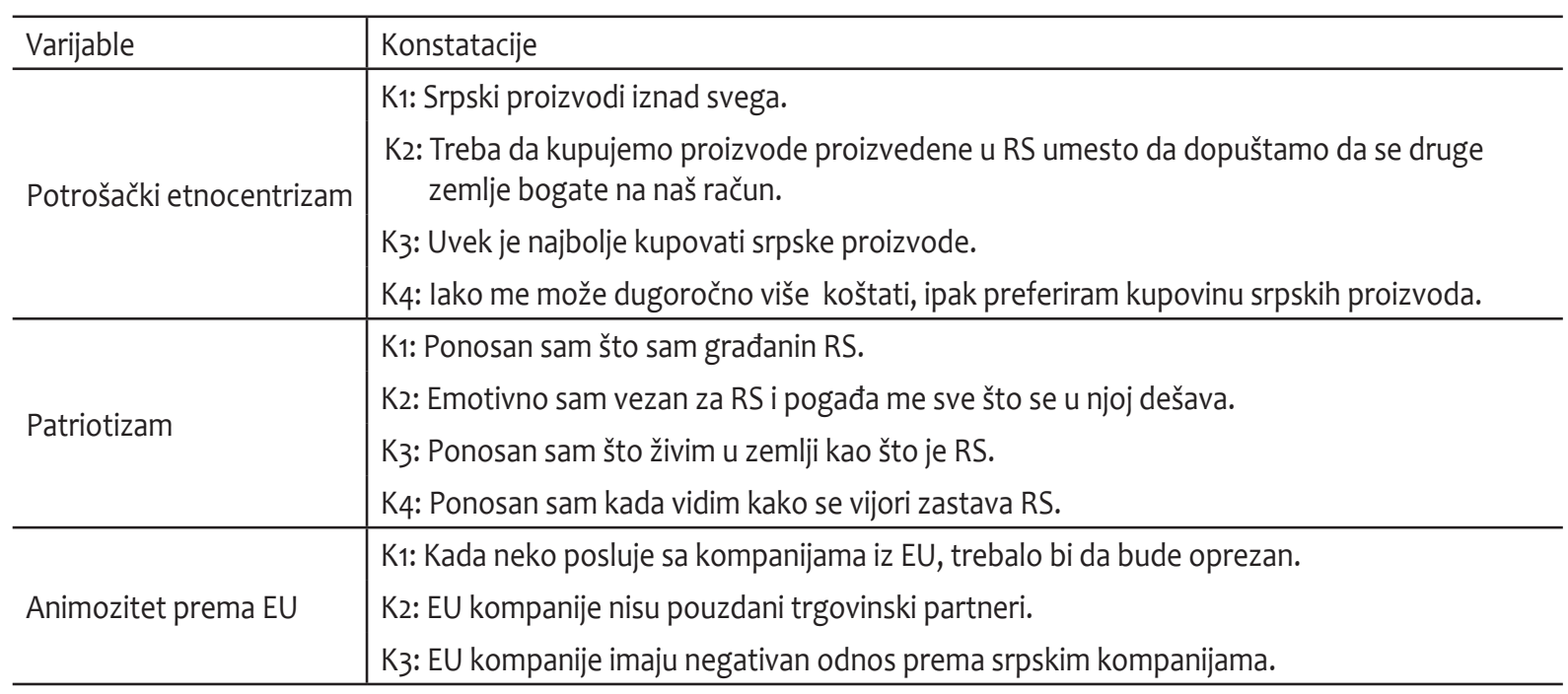


Kako bi se došlo do saznanja da li se između vrednosti aritmetičkih sredina dve posmatrane varijable ispoljavaju statistički značajne razlike, primenjen je upareni t test. Ovaj test pokazuje da li su prosečne vrednosti odgovora na dva pitanja jednake u situaciji kada su isti ispitanici ocenjivali data pitanja, ili promenljive, pri čemu su njihovi odgovori mereni na istoj skali (Soldić-Aleksić i Chroneos-Krasavac, 2009).

Rezultati uparenog t testa pokazuju da je u uzorku prisutan statistički značajno viši stepen patriotizma $\mathrm{u}$ odnosu na intenzitete potrošačkog etnocentrizma i animoziteta prema EU (Tabela 2). S druge strane, u uzorku nema razlika između opšteg stepena potrošačkog etnocentrizma i animoziteta prema EU (p $=0.865>0.05$ ). Analizom rezultata uparenog t testa vidi se da, prema sopstvenim subjektivnim percepcijama, ispitanici ispoljavaju visok stepen patriotizma, ali i umeren stepen potrošačkog etnocentrizma i animoziteta. Generalno, na sedmostepenim skalama, vrednosti aritmetičkih sredina koje su više od ocene 5 mogu se smatrati visokim vrednostima karakterističnim za određeno obeležje. S druge strane, vrednosti niže od 3 se mogu okarakterisati kao niske, dok vrednosti koje se kreću u intervalu 3-5 spadaju u red umerenih vrednosti. Najviši stepen heterogenosti stavova ispitanika prisutan je u slučaju varijable potrošački etnocentrizam (SD = 1.55).

U drugom koraku statističke analize, procenjena je pouzdanost tri posmatrane varijable kao i interna konzistentnost konstatacija koje su upotrebljene za njihovo merenje. Analiza pouzdanosti obično se koristi sagledavanjem vrednosti Cronbach's alpha koeficijenta. Da bi određena varijabla posedovala odgovarajući stepen pouzdanosti, neophodno je da vrednost ovog koeficijenta bude viša od 0.7 (Nunnally, 1978). U slučaju sve tri varijable dobijeni su adekvatni rezultati. Najviši stepen pouzdanosti karakterističan je za potrošački etnocentrizam (Cronbach's alpha = 0.93). I za druge dve varijable karakterističan je visok nivo pouzdanosti (patriotizam: Cronbach's alpha = 0.89; animozitet: Cronbach's alpha $=0.80$ ).

Budući da su u radu testirani uticaji patriotizma i animoziteta na potrošački etnocentrizam, jasno se vidi da predoženi istraživački model sadrži dve nezavisne i jednu zavisnu varijablu. Uobičajeno je da se pre testiranja ovih efekata, proceni validnost koncipiranog istraživačkog modela. U tom kontekstu, primenjena je konfirmativna faktorska analiza. Ova analiza obuhvata seriju testova i izračunavanje niza koeficijenata na osnovu čijih vrednosti se izvodi zaključak o tome da li istraživački model poseduje adekvatan stepen validnosti (RFI - relative fit index; NFI - normed fit index; GFI - goodness-of-fit index; CFI - comparative fit index; TLI - Tucker-Lewis index; IFI incremental fit index; RMSEA - root mean square error of approximation, AVE - average variance extracted; CR composite reliability).

Tabela 2 Rezultati uparenog t testa

\begin{tabular}{|c|c|c|c|c|c|}
\hline Varijable & Ar. sredina & St. devijacija & $\mathrm{t}$ & $\mathrm{df}$ & $\mathrm{p}$ \\
\hline Potrošački etnocentrizam & & & \multirow{2}{*}{$-10.038^{*}$} & \multirow{2}{*}{220} & \multirow{2}{*}{0.000} \\
\hline Patriotizam & 5.23 & 1.40 & & & \\
\hline Potrošački etnocentrizam & 4.32 & 1.55 & \multirow{2}{*}{$-0.170^{\mathrm{ns}}$} & \multirow{2}{*}{220} & \multirow{2}{*}{0.865} \\
\hline Animozitet & 4.33 & 1.42 & & & \\
\hline Patriotizam & 5.23 & 1.40 & \multirow{2}{*}{$8.961^{*}$} & \multirow{2}{*}{220} & \multirow{2}{*}{0.000} \\
\hline Animozitet & 4.33 & 1.42 & & & \\
\hline
\end{tabular}

Napomena: ${ }^{*}$ Rezultat je značajan na nivou 0.01 ; ${ }^{\text {ns }}$ Rezultat nije statistički značajan.

Izvor: Autor 
U Tabeli 3 prikazani su rezultati konfirmativne faktorske analize. Može se konstatovati da su u slučaju svih posmatranih indeksa zabeležene zadovoljavajuće vrednosti. Racio $\chi^{2} /$ df niži je od praga 3 (Byrne, 1998). Vrednosti RFI, NFI, GFI, CFI, TLI i IFI indeksa su približno jednake ili više od praga 0.9 (Hair, Black, Babin, Anderson \& Tatham, 2006), dok je vrednost RMSEA indeksa niža od praga 0.1 (Steiger, 1990). AVE vrednosti sve tri varijable više su od praga 0.5 (potrošački etnocentrizam: AVE $=0.77$; patriotizam: $\mathrm{AVE}=0.67$; animozitet: $\mathrm{AVE}=0.59$ ). Time, model ispunjava svojstvo konvergentne validnosti (Fornell \& Larcker, 1981). Osim toga, vrednosti CR koeficijenta su više od praga $0.7 \mathrm{u}$ slučaju sve tri varijable (potrošački etnocentrizam: $\mathrm{CR}=0.93$; patriotizam: $\mathrm{CR}$ = 0.88; animozitet: $\mathrm{CR}=0.81)$. Važno je istaći da su sva faktorska opterećenja viša od 0.65 i signifikantna su na nivou 0.05 .

Tabela 3 Indeksi usklađenosti istraživačkog modela

\begin{tabular}{c|cc}
\hline $\begin{array}{c}\text { Indeksi } \\
\text { usklađenosti } \\
\text { modela }\end{array}$ & $\begin{array}{c}\text { Preporučene } \\
\text { vrednosti }\end{array}$ & $\begin{array}{c}\text { Vrednosti u } \\
\text { modelu }\end{array}$ \\
\hline$\chi^{2} / \mathrm{df}$ & $<3$ & 2.90 \\
$\mathrm{RFI}$ & $>0.9$ & 0.91 \\
$\mathrm{NFI}$ & $>0.9$ & 0.93 \\
GFI & $>0.9$ & 0.91 \\
CFI & $>0.9$ & 0.96 \\
TLI & $>0.9$ & 0.94 \\
IFI & $>0.9$ & 0.96 \\
RMSEA & $<0.1$ & 0.09 \\
\hline
\end{tabular}

Izvor: Autor
Nakon provere validnosti modela, $\mathrm{u}$ poslednjem koraku statističke analize, primenjen je model strukturalnih jednačina (SEM - structural equation model). Primenom SEM analize izračunata je statistička značajnost $\mathrm{i}$ jačina dva testirana efekta. Rezultati SEM analize prikazani su u Tabeli 4. Oba testirana efekta su statistički značajna $(p<0.01)$. Možemo zaključiti da animozitet prema EU i patriotizam građana RS impliciraju njihovu usmerenost ka kupovini domaćih proizvoda. Time su dokazane obe hipoteze rada. Ipak, na osnovu više vrednosti $\beta$ koeficijenta, vidi se da se patriotizam ističe kao značajnija antecedenta potrošačkog etnocentrizma. Očito, ljubav prema svojoj zemlji u većoj meri određuje potrošačev izbor domaćih proizvoda, nego antipatija prema ekonomskoj politici zemalja EU. Dati istraživački nalazi ukazuju da potrošači mogu percipirati inostrane proizvode kao visoko kvalitetne, ali zbog osećaja ljubavi prema svojoj domovini, ili besa prema EU, deo njih se može opredeliti za kupovinu domaćih proizvoda, uprkos njihovom nižem kvalitetu.

Tabela 4 Testiranje hipoteza

\begin{tabular}{|c|c|c|}
\hline Hipoteza & $\begin{array}{l}\text { Standardi- } \\
\text { zovani } \beta \\
\text { koeficijent }\end{array}$ & Zaključak \\
\hline $\begin{array}{l}\text { H1: Animozitet } \rightarrow \text { Potrošački } \\
\quad \text { etnocentrizam }\end{array}$ & $0.341^{*}$ & $\begin{array}{l}\text { Dokazana } \\
\text { hipoteza }\end{array}$ \\
\hline $\begin{array}{l}\text { H2: Patriotizam } \rightarrow \text { Potrošački } \\
\quad \text { etnocentrizam }\end{array}$ & $0.456^{*}$ & $\begin{array}{l}\text { Dokazana } \\
\text { hipoteza }\end{array}$ \\
\hline
\end{tabular}

Uz navedeno, važno je istaći da nezavisne varijable opisuju ukupno $48.4 \%$ varijabiliteta potrošačkog etnocentrizma $\left(R^{2}=0.484\right)$. Budući da je reč o modelu koji sadrži samo dve nezavisne varijable, ovaj procenat se može okarakterisati kao veoma dobar. Stepen linearne korelacije između posmatrane dve 
varijable iznosi 0.517 i ova vrednost je signifikantna na nivou 0.05. Jasno se može zaključiti da ovde nije prisutan visok stepen linearne korelacije, tako da multikolinearnost ne predstavlja ozbiljniji problem $u$ ovoj studiji. Problem ispoljavanja multikolinearnosti testiran je i sagledavanjem nivoa tolerancije za posmatrane nezavisne promenljive $i$ analizom vrednosti faktora rasta varijanse (VIF - variance inflation factor). S obzirom na to da model sadrži dve nezavisne promenljive, nivo tolerancije iznosi 0.804 (što je značajno viša vrednost od 0.1), dok vrednost faktora rasta varijanse od 1.244 je niža od praga 5 (Field, 2000). Time je dodatno potvrđeno da je multikolinearnost prisutna u niskom stepenu u datom istraživačkom modelu i da su izračunate vrednosti standardizovanih koeficijenata precizne i stabilne.

\section{ZAKLJUČAK}

Koncept potrošačkog etnocentrizma tradicionalno zaokuplja pažnju autora iz oblasti sociologije i ekonomije. I posle više decenija, ova tema ne gubi na aktuelnosti. Štaviše, može se konstatovati da njen značaj raste poslednjih godina, usled dejstva Globalne ekonomske krize. Naime, ekonomska kriza je možda i pravo vreme za podsticanje etnocentričnog ponašanja, odnosno, za usmeravanje građana ka kupovini domaćih proizvoda, u cilju jačanja domaće proizvodnje i smanjenja nezaposlenosti. Ovakva politika naročito je prisutna kada je reč o manje razvijenim, uvozno orijentisanim ekonomijama.

Drugi faktor značajan za izučavanje potrošačkog etnocentrizma i identifikaciju njegovih pokretača, je porast nacionalizma u mnogim zemljama i sve učestalije tenzije u svetu, koje su ne samo ekonomske, već i militarističke prirode. Politička kriza u zemljama Severne Afrike, tenzije na Bliskom istoku, sukobi Indije i Pakistana $\mathrm{u}$ vezi Kašmira, ratni sukobi $\mathrm{u}$ Siriji, samo su neki uzročnici nestabilne ekonomske situacije u različitim regionima, a upravo ova nestabilnost daje dodatnu važnost ovom radu u kojem se primarno testiraju uticaji patriotizma i animoziteta na potrošački etnocentrizam.
Prethodne napomene ukazuju na dobar izbor varijabli korišćenog modela, upravo u današnje vreme, kada patriotizam mnogih nacija jača, ali i animozitet prema ekonomskoj, ili vojnoj politici pojedinih zemalja. U tom kontekstu se i ogleda vrednost i originalnost ovog rada. Naravno, treba imati u vidu da su studije potrošačkog etnocentrizma, sprovedene na teritoriji Zapadnog Balkana veoma retke. Uostalom, posebnu vrednost radu daje koncept istraživačkog modela koji je pružio mogućnost da se analiziraju antecedente potrošačkog etnocentrizma, zbog čega rad u sebi ima naglašenu marketing istraživačku dimenziju. $\mathrm{U}$ radu je korišćena savremena metodologija (kombinacija konfirmativne faktorske i SEM analize) koja je danas standard kada je reč o sličnim terenskim istraživanjima.

Iako je $\mathrm{u}$ radu predstavljen relativno jednostavan model, koji sadrži samo dve potencijalne antecedente potrošačkog etnocentrizma, njihov izbor daje izvesnu specifičnost predloženom modelu. Naime, patriotizam je veoma značajna i često korišćena varijabla $u$ srodnim kulturološkim i ekonomskim istraživanjima, u situacijama identifikacije jačine uticaja različitih faktora na potrošački etnocentrizam. S druge strane, odnos animoziteta i potrošačkog etnocentrizma je fenomen novijeg datuma. U relativno malom broju studija, istraživači su ispitivali uticaj animoziteta na potrošački etnocentrizam. Budući da je ova varijabla retko korišćena u sličnim istraživanjima, njena inkorporacija $\mathrm{u}$ istraživački model daje posebnu vrednost radu. Uostalom, ukoliko se izvrši analiza radova u kojima je korišćen animozitet kao varijabla istraživačkog modela, može se primetiti da je u ovim radovima najčešce analiziran animozitet različitih nacija prema Sjedinjenim Američkim Državama ili Velikoj Britaniji (Rose, Rose \& Shoham, 2009; Ahmed et al, 2013), kao i animozitet azijskih naroda prema ekonomskoj politici Kine ili Japana (Huang, Phau \& Lin, 2010; Cui, Wajda \& Hu, 2012; Lee \& Lee, 2013). Iako su, generalno, u ovim studijama ispitivani stavovi azijskih nacija (naročito sa Bliskog istoka i iz Istočne Azije), postoje i studije u kojima je ispitivan i animozitet evropskih nacija prema ekonomskoj politici Sjedinjenih Američkih Država, ili Nemačke (Riefler \& Diamantopoulos, 2007). Ipak, prema 
saznanjima autora ovog rada, do sada nije ispitivan animozitet građana jedne evropske države prema EU.

Rezultati su potvrdili da se obe nezavisne varijable modela (animozitet i patriotizam) izdvajaju kao statistički značajni pokretači potrošačkog etnocentrizma. Pri tome, patriotizam ima jači uticaj na potrošački etnocentrizam od animoziteta prema EU. Prevashodno, potrošači su fokusirani ka kupovini domaćih proizvoda zbog osećaja ljubavi prema svojoj zemlji. S druge strane, antipatija prema EU je, takođe, značajan faktor usmerenosti građana ka proizvodima iz RS. Ovo, naravno, ne znači da potrošači imaju negativan stav o proizvodima koji dolaze iz EU, ali ih animozitet prema ekonomskoj politici EU može okrenuti ka kupovini domaćih proizvoda. Rezultati su dodatno potvrdili da je u uzorku prisutan visok stepen patriotizma i umeren stepen animoziteta i potrošačkog etnocentrizma. Građani u većoj meri vole svoju zemlju, nego što su oni usmereni ka kupovini domaćih proizvoda. Niži stepen potrošačkog etnocentrizma $\mathrm{u}$ odnosu na patriotizam ukazuje da deo građana, uprkos ljubavi prema svojoj zemlji, više voli da kupuju inostrane proizvode, verovatno zbog njihovog kvaliteta i imidža.

Studija poseduje i izvesna ograničenja. Prvo, istraživanje je sprovedeno $\mathrm{u}$ trenutku, i bilo bi poželjno da se ovakva istraživanja sprovode sukcesivno (na istom uzorku ispitanika), kako bi se pratile promene $\mathrm{u}$ stavovima i ponašanju građana $\mathrm{u}$ procesu kupovine. Drugo, u istraživanju je korišćen jednostavan istraživački model koji sadrži samo dve nezavisne varijable. Poželjno je da budući istraživački modeli sadrže kompleksniju strukturu varijabli. U novim modelima može se testirati i uticaj nacionalizma, nacionalnog identiteta i kulturološke otvorenosti na potrošački etnocentrizam. Time bi istraživanje pružilo bogatije i interesantnije rezultate. Treće, postojeća studija je sprovedena unutar granica samo jedne zemlje. Kros-kulturalna istraživanja potrošačkog etnocentrizma svakako bi sadržala viši nivo vrednosti, jer bi ona pružila mogućnost poređenja stavova pripadnika različitih nacija.

\section{REFERENCE}

Ahmed, Z., Anang, R., Othman, N., \& Sambasivan, M. (2013). To purchase or not to purchase US products: Role of religiosity, animosity, and ethno-centrism among Malaysian consumers. Journal of Services Marketing, 27(7), 551-563. doi: 10.1108/JSM-01-2012-0023

Berns, W. (1997). On patriotism. Public Interest, 127(2), 19-32.

Byrne, B. M. (1998). Structural equation modelling with LISREL, PRELIS, and SIMPLIS: Basic concepts, applications, and programming. Mahwah, NY: Lawrence Erlbaum.

Cheah, I., Phau, I., Kea, G., \& Huang, Y. A. (2016). Modelling effects of consumer animosity: Consumers' willingness to buy foreign and hybrid products. Journal of Retailing and Consumer Services, 30, May, 184-192. doi: 10.1016/j. jretconser.2016.01.018

Cui, A. P., Wajda, T. A., \& Hu, M. Y. (2012). Consumer animosity and product choice: Might price make a difference? Journal of Consumer Marketing, 29(7), 494-506. doi: 10.1108/07363761211275009

Deb, M., \& Chaudhuri, H. R. (2014). Impact of firm's reputation and ethnocentrism on attitude towards foreign products. Marketing Intelligence \& Planning, 32(5), 646-664. doi: 10.1108/ MIP-04-2013-0070

Deb, M., \& Sinha, G. (2016). Impact of culture on religiosity, cosmopolitanism and ethnocentrism. Asia Pacific Journal of Marketing and Logistics, 28(1), 56-72. doi: 10.1108/ APJML-12-2014-0173

Fernández-Ferrín, P., Bande-Vilela, B., Klein, J. G., \& del Río-Araújo, M. L. (2015). Consumer ethnocentrism and consumer animosity: Antecedents and consequences. International Journal of Emerging Markets, 10(1), 73-88. doi: 10.1108/IJOEM-11-2011-0102

Field, A. (2000). Discovering statistics using SPSS for Windows. Sage Publication: Thousand Oaks.

Fornell, C., \& Larcker, D. F. (1981). Evaluating structural equation models with unobservable variables and measurement error. Journal of Marketing Research, 18(1), 39-50. 
Good, K. L., \& Huddleston, P. (1995). Ethnocentrism of Polish and Russian consumers: Are feelings and intentions related? International Marketing Review, 12(5), 35-48. doi:10.1108/02651339510103047

Hair, Jr. J. F., Black, W. C., Babin, B., Anderson R., \& Tatham, R. (2006). Multivariate Data Analysis (6 ${ }^{\text {th }}$ ed.). Upper Saddle River, NY: Prentice Hall.

Han, C. M. (1988). The role of consumer patriotism in the choice of domestic versus foreign products. Journal of Advertising Research, 28(3), 25-32.

Huang, Yu-An, Phau, I., \& Lin, C. (2010). Consumer animosity, economic hardship, and normative influence: How do they affect consumers' purchase intention? European Journal of Marketing, 44(7/8), 909-937. doi: 10.1108/03090561011047463

Klein, J. G., Ettenson, R., \& Morris, M. D. (1998). The animosity model of foreign product purchase: An empirical test in the people's Republic of China. Journal of Marketing, 62(1), 89100. doi: $10.2307 / 1251805$

Kosterman, R., \& Feshbach, S. (1989). Toward a measure of patriotic and nationalistic attitudes. Political Psychology, 10(2), 257-274.

Lee, R., \& Lee, K. T. (2013). The longitudinal effects of a twodimensional consumer animosity. Journal of Consumer Marketing, 30(3), 273-282. doi: 10.1108/07363761311328946

Maričić, B. (2011). Ponašanje potrošača. Beograd, Republika Srbija: Ekonomski fakultet Univerziteta u Beogradu.

Marinković, V., Stanišić, N. i Kostić, M. (2011). Potrošački etnocentrizam građana Srbije. Sociologija 53(1), 43-58. doi: 10.2298/SOC1101043M

Meier-Pesti, K., \& Kirchler, E. (2003). Nationalism and patriotism as determinants of European identity and attitudes towards the euro. Journal of Socio-Economics, 32(6), 685-700. doi:10.1016/j.socec.2003.10.006

Nes, E. B., Yelkur, R., \& Silkoset, R. (2012). Exploring the animosity domain and the role of affect in a cross-national context. International Business Review, 21(5), 751-765. doi:10.1016/j.ibusrev.2011.08.005
Nunnally, J. C. (1978). Introduction to Psychological Measurement. New York, NY: McGraw-Hill.

O'Cass, A., \& Lim, K. (2002). Understanding the younger Singaporean consumers' views of western and eastern brands. Asia Pacific Journal of Marketing and Logistics, 14(4), 54-79. doi: 10.1108/13555850210764954

Prince, M., Davies, M., Cleveland, M., \& Palihawadana, D. (2016). Here, there and everywhere: A study of consumer centrism. International Marketing Review, 33(5), 715-754. doi: 10.1108/IMR-06-2014-0205

Riefler, P., \& Diamantopoulos, A. (2007). Consumer animosity: A literature review and a reconsideration of its measurement. International Marketing Review, 24(1), 87-119. doi: $10.1108 / 02651330710727204$

Rose, M., Rose, G. M., \& Shoham, A. (2009). The impact of consumer animosity on attitudes towards foreign goods: A study of Jewish and Arab Israelis. Journal of Consumer Marketing, 26(5), 330-339. doi: 10.1108/07363760910976583

Shankarmahesh, M. (2006). Consumer ethnocentrism: An integrative review of its antecedents and consequences. International Marketing Review, 23(2), 146-172. doi: 10.1108/02651330610660065

Shimp, T. A. (1984). Consumer ethnocentrism: The concept and preliminary test. Advances in Consumer Research, 11(1), 285-290.

Shimp, A. T., \& Sharma, S. (1987). Consumer ethnocentrism: Construction and validation of the CETSCALE. Journal of Marketing Research, 24(3), 280-289. doi: 10.2307/3151638

Soldić-Aleksić, J., i Chroneos-Krasavac, B. (2009). Kvantitatione tehnike u istraživanju tržišta. Beograd, Republika Srbija: Ekonomski fakultet.

Steiger, J. H. (1990). Structural model evaluation and modification: an interval estimation approach. Multivariate Behavioral Research, 25(2), 173-180. doi: 10.1207/ s15327906mbr2502_4

Sumner, W. G. (1906). Folkways: A study of the sociological importance of usages, manners, customs, mores, and morals. Boston, MA: Ginn and Company. 
van der Toorn, J., Nail, P. R., Liviatan, I., \& Jost, J. T. (2014). My country, right or wrong: Does activating system justification motivation eliminate the liberal-conservative gap in patriotism? Journal of Experimental Social Psychology, 54, 50-60. doi: 10.1016/j.jesp.2014.04.003

Veljković, S. (2009). Uticaj etnocentrizma na potrošače u Srbiji. Marketing, 40(2), 97-106.
Vida, I., Dmitrović, T., \& Obadia, C. (2008). The Role of ethnic affiliation in consumer ethnocentrism. European Journal of Marketing, 42(3/4), 327-343. doi: 10.1108/03090560810852968

Vida, I., \& Reardon, J. (2008). Domestic consumption: rational, affective or normative choice? Journal of Consumer Marketing, 25(1), 34-44. doi: 10.1108/07363760810845390

Primljeno 25. januara 2017, nakon revizije, prihvaćeno za publikovanje 24. aprila 2017. Elektronska verzija objavljena 28. aprila 2017.

Veljko Marinković je vanredni profesor Ekonomskog fakulteta Univerziteta u Kragujevcu, na nastavnim predmetima Ponašanje potrošača i Istraživanje tržišta. Doktorirao je na Ekonomskom fakultetu Univerziteta u Beogradu. Oblasti njegovog naučnog interesovanja su merenje satisfakcije i lojalnosti potrošača, marketing usluga, potrošački etnocentrizam. 


\title{
EFFECTS OF THE REPUBLIC OF SERBIA'S CITIZENS' PATRIOTISM AND ANIMOSITY TOWARDS THE EUROPEAN UNION ON CONSUMER ETHNOCENTRISM
}

\author{
Veljko Marinkovic \\ Faculty of Economics, University of Kragujevac, Kragujevac, The Republic of Serbia
}

Economic, political and militaristic tensions between countries are present throughout the world. The devastating effects of the global financial crisis are still generating the ever-increasing instability of the world economy. Patriotism and nationalism, as well as animosity towards the economic and military policies of certain foreign countries, seem to be on the rise across many countries and nations in recent years. It is precisely the current situation in the world that is favorable for encouraging citizens to purchase domestic products. The policy can be particularly useful for less-developed import-oriented economies. Thus, in the conditions of the economic crisis, the study of consumer ethnocentrism is gaining in importance. The paper examines the effects of the patriotism of the citizens of the Republic of Serbia and animosity towards the EU on consumer ethnocentrism. The results show that both these variables stand out as the statistically significant antecedents of consumer ethnocentrism; however, it should be noticed that patriotism shows a stronger influence on the consumer's orientation towards buying domestic products. The research findings indicate that love of one's country may direct consumer choices towards domestic brands, despite the positive image and high quality of foreign ones. In addition, due to citizens' strong dislike towards the EU economic policy, some of them may decide to buy lower-quality domestic products; however, this does not necessarily negatively affect one's perception of foreign products.

Keywords: consumer ethnocentrism, patriotism, animosity, buying local products, confirmatory factor analysis, structural equation model

JEL Classification: M31, M37 